\title{
Development of Marine and Coastal Tourism Based on Blue Economy
}

\author{
Dimas Tegar R ${ }^{1}$, R.O. Saut Gurning ${ }^{2}$
}

\begin{abstract}
- marine and coastal tourism as one of the largest segments of the maritime economy sector, as well as the largest component of the tourism industry, often leads to controversy over environmental impact and compatibility with other human activities. The application of economic and tourism concepts that are oriented towards environmental conservation and natural resources is one option to overcome the problem. The Blue Economy concept offers an economic concept based on ecosystem principles, where the development will not only generate economic growth but also ensure ecological and social sustainability. In addition, the concept of ecotourism also offers a tourism activity that prioritizes aspects of nature conservation and improving the welfare of the community.
\end{abstract}

Keywords - Blue Economy, Marine and Coastal Tourism, , Sustainable Tourism Development

\section{INTRODUCTION}

I ndonesia is the second largest country in Asia and the seventh in the world, and is also the largest archipelagic country in the world which has a land area of $1 / 3$ parts and oceans $2 / 3$ of the total area. As an archipelagic country, Indonesia has thousands of islands with wide sea so it is possible to have the potential of many natural tourism and diverse. One type of tourism is the marine and coastal tourism. Indonesia has a very strategic position both geographical and climate. indonesia is the biggest marine arena in asia and yatch crossing, from East to West and vice versa, from the Pacific Ocean to the Atlantic. A total of 5000 yachts per year enter Indonesia [1].

Marine and coastal tourism are interconnected. both of them are dependent on the sea and the marine environment. Marine tourism mostly takes place at sea,for example is a cruise and sailing. While coastal tourism takes place in coastal areas that include beachbased tours and recreational activities, such as swimming and sunbathing, coastal walks and resorts. Marine and coastal tourism is a trend that is currently growing rapidly, one of them in Indonesia. Many people start doing this type of tourism. Marine and coastal tourism are the largest segments of the tourism industry. In addition, coastal and marine tourism is also the most important and fastest growing economic activity occurring in the sea.

However, with the development of marine tourism and coastal areas also cause problems of environmental damage, due to construction of buildings and tourism activities. So it needs to be found a step problem solving to support sustainable tourism. The Blue Economy concept can be applied to support sustainable

${ }^{1}$ Dimas Tegar R, Department of Marine Engineering, Institut Teknologi Sepuluh Nopember, Surabaya, 60111, Indonesia. Tegar.17042@mhs.its.ac.id

${ }^{1}$ R.O. Saut Gurning, Department of Marine Engineering, Institut Teknologi Sepuluh Nopember, Surabaya, 60111, Indonesia. sautgurning1@yahoo.com development one of them in marine and coastal tourism. Blue Economy is an economic system based on

environmental conservation and natural resources. It's according to sustainable tourism development. With the concept of Blue Economy is expected to ensure the sustainability of resource availability, ecosystem balance and environmental health, and encourage the effective utilization and management of resources. In addition, the concept of ecotourism can also be applied. Ecotourism is a tourism model that maintain the environment and improving the welfare of the community.

\section{LITERATURE REVIEW}

\section{A. Marine and Coastal Tourism}

Coastal and marine tourism although distinct forms of tourism - are very closely related, due to the water/sea element. Indeed, marine tourism constitutes a form of tourism totally connected to and dependent on the sea and the marine environment. Marine tourism covers a wide range of activities taking place in the deep oceans, the most predominant of which are cruising and sailing. Other leisure water-based activities and nautical sports (often carried out in coastal waters), are scuba diving, underwater fishing, water skiing, windsurfing, tours to maritime parks, wildlife mammal watching, etc. Marine tourism, while the vast majority of activities take place in the sea, their supporting facilities and infrastructure are usually found on land. Such facilities may vary between ports and marinas (serving cruises, yachts, etc.), to oneperson operations (e.g. guides, instructors, etc.), moderate-sized private companies, or even large corporation (cruise-ship companies, etc.) [2].

Coastal tourism, is also a form of tourism in which the water/sea element is predominant and is considered to be the main asset and advantage. Coastal tourism is very closely related to marine (maritime) tourism (since it covers activities taking place at the coastal waters too) although it also covers beach-based tourism and recreational activities, such as swimming and sunbathing, coastal walks, etc. As several scholars argue, the most important and extended type of coastal tourism is the one related to second homes (second home tourism), organized either as part of urban development 
projects (second home developments), or within tourism resorts (i.e. along with hotel facilities, etc.), or autonomously (without previous planning). As regards coastal tourism, all relevant infrastructures and facilities (hotels, resorts, second homes, condos, etc.) are also found exclusively on land and usually much closer to the shoreline. Contrary to marine tourism activities that are attracted to cities and urban environments, facilities related to coastal tourism are usually attracted to the world's most precious coastal natural landscapes, where estuaries, wetlands, coral reefs and other fragile components of the natural ecosystem are encountered [2].

Marine and coastal tourism are both among the oldest forms of tourism and the largest segment of the tourism industry. In addition, coastal and marine tourism is also the most important and fastest growing economic activity occurring in the sea. However, tourism is also one of the main contributors that is responsible for environmental depletion, due to building constructions and tourism activities. Human activities bring implications for quality and quantity of natural resource, such as: the establishment of hotels and resorts, port constructions and boats utilization, reef- walking, snorkelling and diving, fishing, and land-based pollution and sedimentation [3].

Yachts and cruises which represent the largest segment of marine tourism - are responsible for high levels of water pollution (due to waste disposal practices) as well as air pollution (mainly due to gas emissions of cruise ships). At the same time, other marine tourism activities (such as daily trips, underwater fishing, etc.), due to the spatial pattern they follow (close to urban environments and as close as possible to the shoreline), also contribute to the degradation of coastal waters, especially those found close to cities.

Regarding coastal tourism, most coastal tourism activities include the development of second homes and seaside resorts, the pattern of construction is likely to cause damage to the coastal environment. Houses, resorts, hotels, and other hard infrastructures contribute to shoreline changes, water pollution, deteriorate fresh water catchment that leads to seawater intrusion and solid waste. Over the last few decades, the tendency to build new tourism facilities and infrastructure in the fragile coastal zone is still growing. Tourism activities in the waters, such as diving, snorkelling, swimming and other water tourism activities, pose a threat for the coral reef ecosystem and decrease the live coral coverage, resulting in a decrease of its function. The physical function of coral reefs is as a wave damper while the ecological functions to provide environmental services for other ecosystems.

Tourism development is in general responsible for: a) land alteration (particularly in the coastal zone), b) increase of energy consumption, resulting in global warming, release of greenhouse gases, etc. (i.e. effects accelerating climate change), c) extinction of wildlife species and other important components of the natural ecosystem, d) increase of water consumption, especially in water-scarce regions (as are many islands). Yet, coastal and marine tourism activities and infrastructure keep overwhelming the coastal zone [2].

\section{B. Blue Economy}

Since the 1990s the issue of sustainable development (sustainable development) is defined as a development process that optimizes the benefits of natural resources, culture and human. Blue Economy can be a framework in sustainable development. Blue Economy is an economic development paradigm based on ecosystem principles. The Blue Economy conceptualises oceans as "Development Spaces" where spatial planning integrates conservation, sustainable use, oil and mineral wealth extraction, bioprospecting, sustainable energy production and marine transport.

The Blue Economic Concept provides an opportunity to develop more economically and environmentally sound investments and businesses, utilize natural resources more efficiently and less environmentally, produces more efficient and cleaner systems, produces greater products and economic value, increase labor absorption, and provide an opportunity to benefit each contributors more fairly [4].

The Blue Economic Concept was developed to answer the challenge, that the world economic system tend to be exploitative and environmentally destructive. So far the principles of resource efficiency, low carbon, social inclusiveness have grown, but still have not been able to overcome human greed to exploit more natural resources. The essence of the Blue Economy concept is:

a. Learning from nature Blue Economy - imitate the workings of nature (ecosystem), work in accordance with what is provided by nature efficiently and not reduce but instead enrich nature.

b. The logic of ecosystems - The workings of the ecosystem are modeled on the Blue Economy, as water flows from the mountains carrying nutrients and energy to meet the basic needs of the lives of all living things and plants, waste from one to food / energy source to another, so that the ecosystem's life system becomes balanced. Only by gravity energy is distributed efficiently and evenly without external energy extraction. To support the living system, sunlight becomes the energy of photosynthesis of all the contributors who need it.

c. Inspired by 100 innovations - Empirically 100 practical economic innovations have been developed and prove that ecosystems are always working toward higher efficiency levels to drain nutrients and energy without leaving waste to utilize the abilities of all contributors and meet the basic needs of all.

The Blue Economy will ultimately ensure that development will not only generate economic growth, but also ensuring ecological and social sustainability [4]. In general, the Blue Economy can be understood 
as an economic model to encourage sustainable development with a mind-set such as the workings of ecosystems. This is not independent of the principles that exist in the Blue Economy concept, namely:

1. Natural resources efficiency.

2. Zero waste: leave nothing to waste - waste for one is a food for another - waste from one process is resource of energy for the other.

3. Social inclusiveness: self-sufficiency for all - social equity-more job, more opportunities for the poor.

4. Cyclic systems of production: endless generation to regeneration, balancing production and consumption.

5. Open-ended innovation and adaptation: the principles of the law of physics andcontinuous natural adaptation.

\section{Development of Marine and Coastal Tourism}

UU No. 10 2009th on Tourism CHAPTER IV Article 7, 8 , and 9 states that tourism development is based on master plan of tourism development consisting of master plan of national tourism development, provincial tourism development master plan, and master plan of tourism development of regency / city. While the direction of tourism development policy based on PP NO. 50 Year 2011 carries the vision "The realization of Indonesia as a world-class tourism destination, competitive, sustainable, able to encourage regional development and welfare of the people", which is implemented by [1].

1. Tourism Destinations that are safe, comfortable, attractive, accessible, environmentally sound, increasing national, regional and community income.

2. Tourism Marketing that is synergistic, superior, and responsible for increasing the visits of domestic and foreign tourists.

3. A competitive, credible Tourism Industry, create business partnerships, and being responsible for the natural and socio-cultural environment.

4. Organization of Government, Local Government, private and public, human resources, regulation, and operational mechanism effective and efficient in order to encourage the realization of Sustainable Tourism Development.

The development of the tourism sector can directly increase the incomes of the community, especially local people in each tourist destination. In Socio-political, the development of marine tourism for the tour of the archipelago, can foster and strengthen the love of the country, as well as the unity of the nation. Territely, Indonesian tourism has a multisectoral and crossregional character in a concrete manner that will encourage the development of infrastructure and tourism facilities and the creative economy that will drive investment flows and regional development.

Indonesia hopes that the Tourism sector can be an engine of economic and income generating for economic development in Indonesia or a region and certainly contribute in the effort to prosper the community. Through the Ministry of Tourism, Indonesia has targeted the visit of foreign tourists to Indonesia in $2019^{\text {th }}$ as much as 20 million while the achievement in 2014th as much as 9 million. For domestic tourists travel is targeted to increase from 250 million trips in 2014th to 275 million in 2019th [5,10,11].

Development of National Tourism must still uphold the characteristic of the Indonesian people, especially the potential of nature, culture and local wisdom of the local community. Religious norms and cultural values in every aspect of life will color the development of national tourism in order to create a conducive life to ideology, politics, economy, social, culture and defense of security. The development of the region should also refer to the potential of good areas of tourism potential (natural and cultural tourism) as well as creative products of community creativity.

In the tourism development needs to be considered some elements that support tourist destinations. Buhalis [8] suggests most destinations comprise of a core of the following components named as the 6 As framework, which includes attraction, accessibility, amenities, available packages, activities and ancillary services. Apart from that, World Tourism Organization $[6,9,12]$ describes the tourism destinations of six elements, namely: Attraction, Public and Private Amenities, Accesibilities, Human Resources, Image and Character, Price.

1. Attractions. Generally the focus of attention of visitors and can provide initial motivation for tourists to visit. Attractions can be categorized as a natural tourist attraction (beaches, mountains, parks, weather), buildings, culture.

2. Amenities. Supportive services and facilities include basic infrastructure for visitors, public transportation, and roads and direct services for visitors such as accommodation, visitor information, recreational facilities, guides, operators and dining and drinking facilities as well as shopping facilities.

3. Accessibility. The ease of visitors to reach the destination by road, air, rail and sea lane.

4. Human Resources. Tourism is a labor-intensive industry and interaction with local communities is an important aspect of tourism experience. Trained tourism workers and communities who realize the benefits and responsibilities associated with tourism growth are an indispensable element and need to be managed in accordance with tourism destination strategies.

5. Image. Is a unique or an important picture in attracting visitors to visit. Included in the image of the destination is the uniqueness, scenery, scene, environmental quality, safety, service level, and friendliness.

6. Price. Price is an important aspect of competition among tourist destinations. The price factor relates 
to transportation costs to and from destinations and the cost of accommodation services, attractions,

Referring to the blue economic concept can be described the implementation of the six elements of tourism destinations above. In terms of attractions, need to be created nature attractions that are environmentally friendly and nature conservation. So that there will be no decrease / damage both in terms of environment and the availability of flora and fauna. For example of natural attractions are turtl conservation, coral reef conservation, etc. Areas of tourist attractions that are vulnerable to damage need to be identified, and given the limits of tourism activities that can be done in the area.

In terms of amenities, need to be used energy sources and technologies that are environmentally friendly, for example solar panels, biogas, air conditioning which use freon R23, etc. In addition, it is necessary to build a waste treatment plant on the existing infrastructure such as hotels, resorts, shopping place etc, so that the waste produced can be treated well and not pollute the

\section{food and tours.}

environment. Infrastructure development should pay attention to the coastal ecosystem area so that the development undertaken does not damage the existing ecosystem. For example the construction of hotels and resorts is not built in the fragile coastal zone or in the estuary.

In terms of Accessibility, using modes of transportation that are low emissions, for example electric cars or cars that use euro five emission standards. In terms of human resources, knowledge and skills of tourism workers need to be improved. It will create better service and will bring in more tourists so that economic growth will increase. In terms of image, same as the attractions in its implementation. In terms of price, the price offered must compete and not turn off other business units. Below is the example of comparison about six elements of destination.

TABLE 1

COMPARISON OF SIX ELEMENTS OF DESTINATION

\begin{tabular}{|c|c|c|c|}
\hline No & $\begin{array}{l}\text { Comparison } \\
\text { aspects }\end{array}$ & Lampung Bay tourism & Maldives tourism \\
\hline 1 & Attractions & $\begin{array}{l}\text { The quality of natural landscape or beaches is } \\
\text { very good the diversity of beach tourism } \\
\text { activities is very good (swimming, relaxing, } \\
\text { snorkeling, diving and various water games } \\
\text { (parasailing, flying fish, banana boat, donut, } \\
\text { canoe, jetski, snorkeling, and glass bottom } \\
\text { boat) there is the uniqueness of local } \\
\text { culture }\end{array}$ & $\begin{array}{l}\text { The quality of natural landscape or beaches is } \\
\text { very good tourism activities is very good } \\
\text { (Snorkeling, diving, water sports, surfing, whale } \\
\text { submarine, big game fishing, nigh fishing, island } \\
\text { hopping) there is the uniqueness of local } \\
\text { culture, arts and crafts, festivals and traditional } \\
\text { food }\end{array}$ \\
\hline 2 & Amenities & $\begin{array}{l}\text { The availability of banking services is less } \\
\text { Hotels and lodgings are less shops and } \\
\text { restaurants are enough }\end{array}$ & $\begin{array}{l}\text { The availability of banking services is very good } \\
\text { (Banks, ATMs and money changers) the } \\
\text { availability of Hotels and lodgings are very good } \\
\text { (Resorts, Hotel, Liveaboard (cruise)) the } \\
\text { availability of shops and restaurants are very good }\end{array}$ \\
\hline 4 & $\begin{array}{l}\text { Human } \\
\text { Resources }\end{array}$ & $\begin{array}{l}\text { The quality of employee skills, responses to } \\
\text { complaints, and adequacy of the number of } \\
\text { employees are quite good Local peoples are } \\
\text { friendly }\end{array}$ & $\begin{array}{l}\text { The quality of employee skills are very good } \\
\text { Local people are very friendly }\end{array}$ \\
\hline 5 & Image & $\begin{array}{l}\text { The uniqueness and environmental } \\
\text { conditions are very good clean and free from } \\
\text { air pollution and noise very safe }\end{array}$ & $\begin{array}{l}\text { Has unique landscape and culture clean and } \\
\text { free from pollution very safe }\end{array}$ \\
\hline
\end{tabular}

\section{RESULT AND DISCUSSION}

From the above discussion we can know that marine tourism and coastal are interconnected. Both types of tourism utilize the diversity of marine biological resources and the marine environment. Marine and coastal tourism are both one of the oldest forms of tourism and the largest segment of the tourism industry. In addition, marine and coastal tourism is also the most important and fastest growing economic activity occurring in the sea. Marine tourism activities take place at sea while supporting facilities and infrastructure are usually found on land. While infrastructure and coastal tourism facilities are also found on land and usually 
closer to the coastline. Contrary to marine tourism activities attracted to municipalities and urban environments, facilities related to coastal tourism are usually attracted to the coastal natural landscape, where estuaries, wetlands, coral reefs and other fragile components of the ecosystem nature are encountered. It can cause environmental damage due to building construction and tourism activities.

Sustainable tourism development needs to be done to address these issues. An understanding that places tourism as a means of exploitation must change in action based on sustainability values. The Blue Economic Concept can be applied to the tourism sector especially in marine and coastal tourism. The Blue Economic Concept focuses on sustainable development and utilization of natural resources based on environmental conservation. This is in line with the development of sustainable tourism. Application of six elements of tourism destinations in accordance with the blue economy concept also needs to be done. So in the end, Blue Economy will ultimately ensure that an undertaken development will not only generate economic growth but also ensure ecological and social sustainability. In general, the Blue Economy can be understood as an economic model to encourage sustainable development with a mind- set such as the workings of ecosystems. So it is appropriate if the Blue Economy concept applied to the development of sustainable tourism.

In addition to the concept of blue economy, the concept of ecotourism can also be applied to support sustainable tourism development. Ecotourism is a tourism activity which is environmentally minded by prioritizing of nature conservation aspects, improving the welfare of the community and learning/education aspects. Ecotourism is an effort to maximize and simultaneously preserve the potential of natural resources and culture to be used as a source of sustainable income [7]. It can be seen that the concept of ecotourism is in line with the blue economic concept which equally requires economic growth and ecological and social sustainability.

\section{CONCLUSION}

In conducting tourism development (marine and coastal tourism) should pay attention to six elements of tourism destinations based on the blue economy concept. In addition, the concept of ecotourism can also be applied. By applying these concepts, development and mining of tourism should be able to grow in harmony with the principles of innovative and sustainable development. So it is expected to generate economic growth and ecological and social sustainability.

\section{REFERENCES}

[1] Priyono, "Strategi Pengembangan Industri Pariwisata Bahari. Yogyakarta, Kementrian Pariwisata dan Ekonomi Kreatif Republik Indonesia," 2014.

[2] Papageorgiou, M, "Coastal and marine tourism: A challenging factor in Marine Spatial Planning. Ocean \& Coastal Management," 129, 44-48, 2016.

[3] Kurniawan, F., Adrianto, L., Bengen, D. G. \& Prasetyo, L. B., Vulnerability assessment of small islands to tourism: The case of the Marine Tourism Park of the Gili Matra Islands, Indonesia. Global Ecology and Conservation, 6, 308-326., 2016.

[4] Indonesia, D. K, “Kebijakan Ekonomi Kelautan dengan Model Ekonomi Biru. Jakarta: Dewan Kelautan Indonesia”, 2012.

[5] Abdillah, D., "Marine Tourism Development In Lampung Coastal Bay. Destination of Indonesian Tourism" 1, 45-66., 2016

[6] Organization, W. T., "A practical guide to tourism destination management, World Tourism Organization”, 2007.

[7] Handayawati, H, "Potensi Wisata Alam Pantai-Bahari. PM PSLP PPSUB", 2010

[8] Buhalis, D. "Marketing the competitive destination of the future. Tourism management,21, 97-116., 2000.

[9] Kathijotes, N, "Keynote: Blue economy-environmental and behavioural aspects towards sustainable coastal development. Procedia-Social and Behavioral Sciences", 101, 7-13, 2013.

[10] Mulazzani, L. \& Malorgio, G. "Blue growth and ecosystem services. Marine Policy”, 85, 17-24, 2013.

[11] Pattimukay, K. "Economic Value and Potential for Tourism Development of Twal Pombo Island, Salahutu, Central Maluku, Maluku. Widyariset", 18, 135-144. 2015.

[12] Official Publication of Maldives Marketing and Public Relations Corporation," Maldives Visitors Guide. pp. 8-48, 2007. 